\title{
Assessment of Genetic Diversity among 16 Promising Cultivars of Ginger Using Cytological and Molecular Markers
}

Sanghamitra Nayak ${ }^{\mathrm{a}, *}$, Pradeep K. Naik ${ }^{\mathrm{a}}$, Laxmikanta Acharya ${ }^{\mathrm{b}}$,

Arup K. Mukherjee ${ }^{\mathrm{b}}$, Pratap C. Panda ${ }^{\mathrm{b}}$, and Premananda Das ${ }^{\mathrm{c}}$

a Department of Bioinformatics, Jaypee University of Information Technology, Waknaghat, Solan 173215, Himachal Pradesh, India. Fax: 91-1792-245362.

E-mail: sanghamitran@yahoo.com

b Regional Plant Resource Centre, Bhubaneswar 751015, Orissa, India

c Indian Institute of Technology, Kharagpur, West Bengal, India

* Author for correspondence and reprint requests

Z. Naturforsch. 60 c, 485-492 (2005); received September 10/November 16, 2004

Ginger (Zingiber officinale Roscoe) is an economically important plant, valued all over the world. The existing variation among 16 promising cultivars as observed through differential rhizome yield (181.9 to $477.3 \mathrm{~g}$ ) was proved to have a genetic basis using different genetic markers such as karyotype, 4C nuclear DNA content and random amplified polymorphic DNA (RAPD). The karyotypic analysis revealed a differential distribution of A, B, C, D and $\mathrm{E}$ type of chromosomes among different cultivars as represented by different karyotype formulas. A significant variation of $4 \mathrm{C}$ DNA content was recorded in ginger at an intraspecific level with values ranging from 17.1 to $24.3 \mathrm{pg}$. RAPD analysis revealed a differential polymorphism of DNA showing a number of polymorphic bands ranging from 26 to 70 among 16 cultivars. The RAPD primers OPC02, OPA02, OPD20 and OPN06 showing strong resolving power were able to distinguish all 16 cultivars. The extent of genetic diversity among these cultivars was computed through parameters of gene diversity, sum of allele numbers per locus and Shannon's information indices. Cluster analysis, Nei's genetic similarity and genetic distances, distribution of cultivars into special distance classes and principal coordinate analysis and the analysis of molecular variance suggested a conspicuous genetic diversity among different cultivars studied. The genetic variation thus detected among promising cultivars of ginger has significance for ginger improvement programs.

Key words: Ginger, Karyotype, RAPD

\section{Introduction}

Zingiber officinale is rich in secondary metabolites such as oleoresin. It possesses an unique combination of properties like anti-inflammatory, aphrodisiac, antioxidant and antibacterial activity (Mohanty and Panda, 1994). It is cultivated for the underground rhizomes which are used for culinary and drug preparation. Ginger is best known for its ability to lessen the nausea and vomiting associated with motion sickness and hypermesis gravidarum. Ancient physicians used ginger as a carminative and anti-fermenting medicine. Ginger is believed to be originated in India and was introduced in China at a very early date. Although ginger is an asexually propagated crop, it displays great morphological diversity. Until recently, several promising cultivars released formally are characterized on the basis of morphological and biochemical data, oleoresin content and yield potential. However these characters differ under var- ying environmental conditions making characterization of different ginger cultivars a complicated task. In addition to this practical concern the continued release of new cultivars makes the development of new techniques for genetic purity determination even more essential. Due to resurgence of interest in the commercial development of different cultivars of ginger as new spice crops, it has become necessary to precisely characterize the genetic diversity that exists in cultivars, advanced selections and native population. This is one step towards providing accurate genetic information for future breeding and germplasm collection efforts (Huang et al., 2000). Unlike morphological markers, cytological (chromosome number, karyotype, nuclear DNA content) and molecular markers (RAPD) are not prone to environmental influences and accurately characterize the plants portraying the extent of genetic diversity among taxa (Bennett and Smith, 1991; Rodriguez et al., 1999; Das et al., 2001). 
In the past decade, DNA polymorphism has become the marker of choice for the identification and characterization of plants. It is a relatively reliable, generally applicable method to obtain large samples of markers from any species of plant. However, each marker system samples a different fraction of the genomes and therefore has a different resolving power, range of applicability and probability of homology. The random amplified polymorphic DNA (RAPD) technique has been widely used in cultivar identification programs (Schnell et al., 1995) and in assessing genetic variation of plant species at the DNA level, because of its cost effectiveness and simple operation without requiring a prior knowledge of species DNA sequences (Williams et al., 1990; Frankel et al., 1995). RAPDs reveal similar patterns of genetic diversity when compared with other marker types (Aagaard et al., 1998) and can be performed more rapidly than most other methods (Morell et al., 1995). RAPDs tend to provide more diagnostic population race and species specific markers. RAPD analysis has been successfully used for clarification of the phytogeographical questions (Friesen and Blattner, 2000).

The objectives of this study were to (1) fingerprint ginger cultivars for identification and (2) detect the genetic diversity and relatedness of 16 cultivars sampled from different geographical regions using karyotypic analysis, 4C DNA content and RAPD analysis. In this study, many analytical procedures such as a $n-j$ method, bootstrapping, spatial genetic structure analysis (SGS), and analysis of molecular variance (AMOVA) have been widely used to derive genetic distances among cultivars and to assess the structure of genetic data in a reduced dimensional space.

\section{Materials and Methods}

\section{Plant materials}

Sixteen promising cultivars of ginger (Zingiber officinale) were included in the present study which were collected from the turmeric germplasm collection of the Orissa University of Agriculture and Techology (OUAT), Bhubaneswar, Orissa, India. These cultivars were initially collected from different parts of India (Table I) and were grown in clonal repositories. The cultivars were selected by one or more of the following criteria: agronomic performance, current production acreage and historical significance. The rhizomes were planted in the field during May and were harvested after 8 months, i.e during January. The mean rhizome yield per plant was calculated taking the average of 3 clumps during harvest.

\section{Karyotype analysis}

Young and healthy root-tips of different cultivars of ginger were pre-treated in a $(0.02 \mathrm{M})$ hydroxyquinoline mixture $(1: 1)$ for $3.5 \mathrm{~h}$ at $14{ }^{\circ} \mathrm{C}$ followed by overnight fixation in propionic ethanol. Chromosome staining was made in $2 \%$ lacto propionic orcin after cold hydrolysis in $5 \mathrm{~N} \mathrm{HCl}$ for 7 min. Root-tips were squashed in $45 \%$ propionic acid. Ten well scattered metaphase plates were selected for karyotype analysis of each species. The chromosome morphology was determined following the method of Das et al. (1998).

\section{C DNA content}

For Feulgen cytophotometric estimation of $4 \mathrm{C}$ DNA, ten fixed root-tips from each cultivar $(2 \mathrm{n}=$ 22 chromosomes) were hydrolysed in $1 \mathrm{~N} \mathrm{HCl}$ for $12 \mathrm{~min}$ at $60^{\circ} \mathrm{C}$, washed in distilled water and stained in Schiff's reagent for $2 \mathrm{~h}$ at $14^{\circ} \mathrm{C}$; each root-tip squash was prepared in $75 \%$ acetic acid. Ten scorings were made from each slide and the 4C DNA content was estimated from metaphase chromosomes using a NIKON Optiphot microscope with a microspectrophotometer following the method of Sharma and Sharma (1980) with monochromatic light at $550 \mathrm{~nm}$. In situ DNA values were obtained on the basis of optical density measurements which were converted to picograms (pg) using Vant Hoff's 4C nuclear DNA value (67.1 pg) for Allium cepa as standard (Das et al., 1998). ANOVA were performed among the nuclear DNA values to find out the differences at cultivar level.

\section{Isolation of DNA}

Total plant DNA was isolated from fresh and young leaves. The leaves were harvested freshly and washed thoroughly with cold autoclaved distilled water and then blotted to dry. About $2 \mathrm{~g}$ leaf was excised from the upper tip portion of the buds. DNA extraction was done on the day of collection.

The genomic DNA was isolated following the protocol of Doyle and Doyle (1990) with a little modification. Insoluble poly(vinylpyrrolidone) was added to the leaf tissue prior to grinding. The crude DNA was purified with RNase A (@60 $\mu \mathrm{g}$ $\mathrm{ml}^{-1}$ of DNA solution) followed by washing with 
purified chloroform/isoamylalcohol (24:1). To test the quality and quantity of the purified DNA, the samples were electrophoresed in a $0.8 \%$ agarose gel along with a known amount of uncut lambda DNA (Bangalore Genei Pvt. Ltd, Bangalore, India) as standard. The sample DNA was diluted as $25 \mathrm{ng} \mu \mathrm{l}^{-1}$ for RAPD-PCR analysis.

\section{RAPD amplification}

Twenty random decamer primers (Operon Tech., USA) from A, C, D and N series (OPA02, 03, 04, 08, 16; OPAF14; OPC02, 05; OPD03, 07, 08, 18, 20; and OPN02, 03, 04, 06, 07, 10, 12) were used for RAPD analysis. RAPD assays were performed in a final volume of $25 \mu \mathrm{l}$ containing $10 \mathrm{~mm}$ Tris- $\mathrm{HCl}$ [tris(hydroxymethyl)aminomethane], $\mathrm{pH}$ 9.0, $1.5 \mathrm{~mm} \mathrm{MgCl}_{2}, 50 \mathrm{~mm} \mathrm{KCl}$ and $0.01 \%$ gelatin, $200 \mu \mathrm{M}$ of each dNTPs, $0.4 \mu \mathrm{M}$ primer, $25 \mathrm{ng}$ template DNA and 0.5 unit of Taq DNA polymerase (Bangalore Genei, Bangalore, India). The RAPD analysis was performed as per the methodology described by Williams et al. (1990) using a Gene Cycler (Bio Rad, USA). The first cycle consisted of denaturation of template DNA at $94^{\circ} \mathrm{C}$ for $5 \mathrm{~min}$, primer annealing at $37^{\circ} \mathrm{C}$ for $1 \mathrm{~min}$ and primer extension at $72{ }^{\circ} \mathrm{C}$ for $2 \mathrm{~min}$. In the next 42 cycles the period of denaturation was reduced to $1 \mathrm{~min}$ at $92^{\circ} \mathrm{C}$ while the primer annealing and primer extension time remained the same as in the first cycle. The last cycle consisted of only primer extension $\left(72^{\circ} \mathrm{C}\right)$ for $7 \mathrm{~min}$. The reactions ended with an indefinite hold at $4{ }^{\circ} \mathrm{C}$.

The amplification products were electrophoresed in $1.5 \%$ agarose gel containing ethidium bromide (@ $0.5 \mu \mathrm{g} \mathrm{ml}^{-1}$ ) in TAE buffer ( $40 \mathrm{~mm}$ Tris base, $20 \mathrm{~mm}$ sodium acetate, $20 \mathrm{~mm}$ EDTA, glacial acetic acid to $\mathrm{pH} 7.2$ ) for $3 \mathrm{~h}$ at $60 \mathrm{~V}$. A total of $2.5 \mu \mathrm{l}$ loading buffer (1.0 X TAE, $50 \%$ glycerol, $0.25 \%$ bromophenol blue and $0.25 \%$ xylene cyanol) was added to each reaction before electrophoresis. After electrophoresis, the gels were observed under an UV-transilluminator, documented in Gel-Doc 2000 (Bio-Rad) and photographed.

\section{Resolving power}

According to Prevost and Wilkinson (1999) the resolving power $(R p)$ of a primer is: $R p=\Sigma I B$, where $I B$ (band informativeness) takes the value of: 1 - $[2 \times(0.5-p)], p$ being the proportion of the 16 genotypes (ginger cultivars analyzed) containing the band.

\section{Data collection and analysis}

The relatedness of DNA samples was assessed by comparing RAPD fragments of DNA separated according to their sizes and the presence/absence of shared fragments. The banding patterns obtained from RAPD were scored as present (1) or absent (0). Jaccard's coefficient similarity was measured and a dendrogram based on similarity coefficients generated by the $n-j$ method was obtained. POPGENE software was used to calculate Nei's unbiased genetic distance among different species with all markers, including monomorphic markers. Nei's unbiased genetic distance is an accurate estimate of the number of gene differences per locus when populations are small. Species diversity $(H s)$ and total gene diversity $(H t)$ (Nei, 1973) were calculated within the species and within five major groups (as per their collection site) by POPGENE software. The RAPD data were subjected to a hierarchical analysis of molecular variance (AMOVA) as described by Excoffier et al. (1992) using ARLEQUIN 2.00 (Schneider et al., 2001).

\section{Results and Discussion}

\section{Rhizome yield}

The rhizome yield per plant of 16 cultivars of ginger varied significantly from $181.9 \mathrm{~g}$ in Singhaghara to $477.3 \mathrm{~g}$ in Gorubathaney after first harvest (Table I). The existing variations among the ginger cultivars quantified through rhizome yield were proved to have a genetic basis as revealed by different karyotype formula, differential DNA content and DNA polymorphism using RAPD markers.

\section{Karyotype analysis and $4 C D N A$ content}

The chromosome number of all cultivars comprised $2 \mathrm{n}=22$ chromosomes whereas the karyotype formula revealed differences in the chromosome structure (Table I). Similar results with differential karyotype were also obtained in 7 cultivars of ginger by Das et al. (1998). Structural changes might have played a vital role in inducing differences at cultivar level (Das et al., 1998). All the types of chromosomes such as A, B, C, D and $\mathrm{E}$ were found in the genome of the cultivar Gorubathaney.

The 4C nuclear DNA content of all 16 promising cultivars is mentioned in Table I. The 4C DNA 
Table I. Sixteen cultivars of ginger collected from different parts, their cytogenetic and polymorphic features.

\begin{tabular}{|c|c|c|c|c|c|c|c|}
\hline $\begin{array}{l}\text { Sl. } \\
\text { No. }\end{array}$ & $\begin{array}{l}\text { Name of } \\
\text { cultivar }\end{array}$ & $\begin{array}{l}\text { Sampling } \\
\text { site }\end{array}$ & $2 n$ & Karyotype formula & $\begin{array}{l}\text { 4C DNA } \\
\text { content }[\mathrm{pg}] \\
\text { (mean } \pm \mathrm{S} . \mathrm{E} .)\end{array}$ & $\begin{array}{l}\text { Rhizome yield }[\mathrm{g}] \\
(\text { mean } \pm \text { S. E.) }\end{array}$ & $\begin{array}{l}\text { Sum of poly- } \\
\text { morphic bands } \\
\text { using all primers }\end{array}$ \\
\hline 1 & Suruchi & Orissa & 22 & $8 \mathrm{C}+6 \mathrm{D}+8 \mathrm{E}$ & $21.3 \pm 0.15$ & $274.9 \pm 0.40$ & 70 \\
\hline 2 & Suprabha & Orissa & 22 & $2 B+4 C+4 D+12 E$ & $23.1 \pm 0.12$ & $242.3 \pm 0.42$ & 68 \\
\hline 3 & Surabhi & Orissa & 22 & $8 C+10 D+4 E$ & $22.9 \pm 0.06$ & $261.3 \pm 0.43$ & 55 \\
\hline 4 & Singhaghara & Orissa & 22 & $4 A+6 C+4 D+8 E$ & $22.6 \pm 0.12$ & $181.9 \pm 0.41$ & 62 \\
\hline 5 & Phiringia & Orissa & 22 & $4 A+4 C+8 D+6 E$ & $23.2 \pm 0.13$ & $243.3 \pm 0.52$ & 59 \\
\hline 6 & S558 & Solan & 22 & $22 \mathrm{~A}+14 \mathrm{C}+6 \mathrm{E}$ & $23.9 \pm 0.12$ & $313.7 \pm 0.59$ & 62 \\
\hline 7 & S547 & Solan & 22 & $2 \mathrm{C}+8 \mathrm{D}+12 \mathrm{E}$ & $23.3 \pm 0.16$ & $253.4 \pm 0.50$ & 65 \\
\hline 8 & S666 & Solan & 22 & $2 B+4 C+8 D+8 E$ & $21.8 \pm 0.17$ & $214.3 \pm 0.50$ & 26 \\
\hline 9 & S646 & Solan & 22 & $6 \mathrm{~A}+10 \mathrm{D}+6 \mathrm{E}$ & $24.3 \pm 0.1$ & $366.5 \pm 0.64$ & 37 \\
\hline 10 & Nangrey & Sikim & 22 & $2 \mathrm{~A}+8 \mathrm{C}+8 \mathrm{D}+4 \mathrm{E}$ & $17.1 \pm 0.08$ & $304.0 \pm 0.60$ & 60 \\
\hline 11 & Gorubathaney & Sikim & 22 & $4 A+4 B+6 C+6 D+2 E$ & $22.2 \pm 0.03$ & $477.3 \pm 0.70$ & 47 \\
\hline 12 & Anamica & Andhra & 22 & $4 A+2 B+10 C+6 D$ & $20.2 \pm 0.13$ & $275.5 \pm 0.55$ & 30 \\
\hline 13 & Zaherabad & Andhra & 22 & $2 \mathrm{~A}+2 \mathrm{~B}+10 \mathrm{D}+8 \mathrm{E}$ & $21.5 \pm 0.09$ & $280.1 \pm 0.61$ & 61 \\
\hline 14 & Wynad local & Kerala & 22 & $6 \mathrm{~A}+2 \mathrm{C}+14 \mathrm{D}$ & $22.9 \pm 0.03$ & $261.3 \pm 0.41$ & 65 \\
\hline 15 & Nadia & West Bengal & 22 & $6 \mathrm{~A}+8 \mathrm{C}+4 \mathrm{D}+4 \mathrm{E}$ & $21.2 \pm 0.12$ & $209.3 \pm 0.50$ & 69 \\
\hline 16 & Rajgarh & M.P & 22 & $4 C+8 D+10 E$ & $18.2 \pm 0.02$ & $270.0 \pm 0.55$ & 60 \\
\hline
\end{tabular}

content was found to be lowest (17.1 pg) in Nangrey and highest $(24.3 \mathrm{pg})$ in S646. The ANOVA test showed that the variation in the nuclear DNA content among 16 cultivars of ginger was significant at an $1 \%$ level $(F=273.17)$. Such intraspecific variations are in close agreement with the reports of other workers (Price et al., 1980; Das et al., 1998). Although the 16 cultivars studied comprised a constant chromosome number $(2 n=22)$ the DNA amount differed significantly and the differences in the DNA content depend on the repetitive DNA amount (Flavell et al., 1977). The variability in the DNA content in different cultivars might be attributed to the loss or addition of many repeats in the genomes through alterations in the micro- and macro-environment during evolution in the selection of new cultivars (Price et al., 1980; Das et al., 1998). The variability of DNA amount could be attributed to the loss or addition of highly repetitive DNA sequences rather than AT or GC-rich sequences in a genome (Martel et al., 1997) which reached a certain level and got stabilized during micro-evolution and gradual selection.

\section{RAPD marker size and patterns}

The RAPD technique has been successfully used in a variety of taxonomic and genetic diversity studies (Rodriguez et al., 1999) and was found by us to be suitable for use with ginger cultivars in its ability to generate reproducibly polymorphic markers. The need for preservation of genetic resources of ginger creates an incentive for the determination of the genetic variability present in it. A total of 16 cultivars was fingerprinted using 20 RAPD markers. 145 (an average of 7.25 bands per primer) RAPD loci were scored out of which 101 (69.66\%) were polymorphic and only 44 (30.34\%) were monomorphic bands. Out of 44 monomorphic bands 7 (15.91\%) fragments were cultivar specific fragments. The number of amplification

Table II. Four of twenty primers used to amplify all DNA samples collected from 16 cultivars of ginger plants (Zingiber officinale) with the generated bands by each primer.

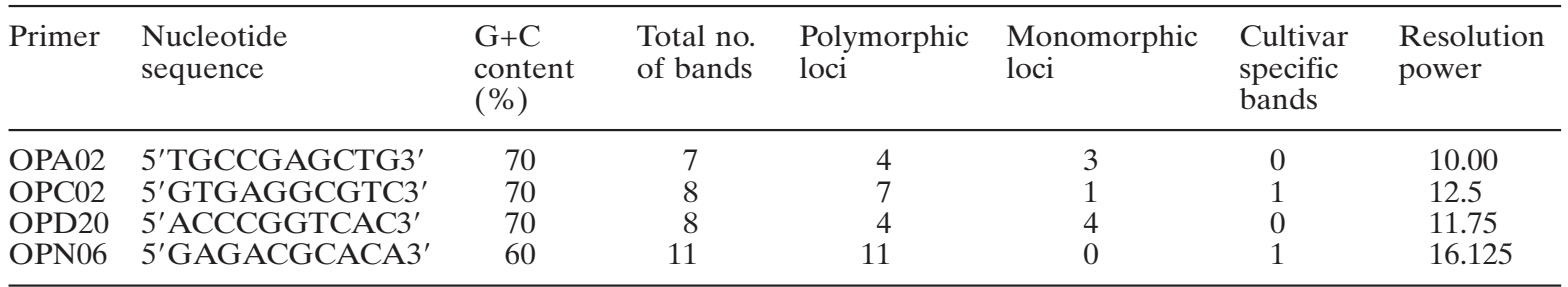


fragments produced per primer as well as their size range were analytically appropriate, conforming to those recorded with certain other plants examined analogously (Ho et al., 1997). The observed high proportion of polymorphic loci suggests that there is a profound intraspecific variation existing among the ginger cultivars. The most responsive primers (in terms of number of amplification products and/or responding genotypes) are listed in Table II. Three to 14 types of amplification fragments (monomorphic + polymorphic) were produced by each primer in different cultivars. The resolving power of the 20 RAPD primers ranged from 4.75 for primer OPAF14 to 16.125 for primer OPN06. Besides its high resolving power value, RAPD primer OPN06 is able to distinguish all 16 ginger cultivars.

\section{Dendrogram obtained with RAPD markers}

The dendrogram obtained using the similarity matrix coefficient presents two main clusters (A and B) with 12 and 4 cultivars (Fig. 1). Cluster A has two subclusters (A1 and A2), having 3 and 7 cultivars. The cultivars S558 and Phiringia shared a different node under cluster A. No clear clustering of the cultivars was found according to their geographical region. The relative closeness of the different cultivars is revealed in Table III. The minimum distance was found to be in between S547 and Singhaghara (0.078) and the maximum distance was in between S666 and Phiringia (0.315).

\section{Genetic identity and diversity analysis}

A relatively high genetic variation was detected among the ginger cultivars. The values of genetic similarities ranged from 0.5379 between S666 and Suruchi to a maximum of 0.9379 between S547 and Singhaghara and the genetic distances ranged from 0.0641 between Singhaghara and S547 to 0.6200 between Suruchi and S666. A wide genetic variation between cultivars of ginger was evident from the high number of polymorphic markers and unique bands, even though the survey was lim-

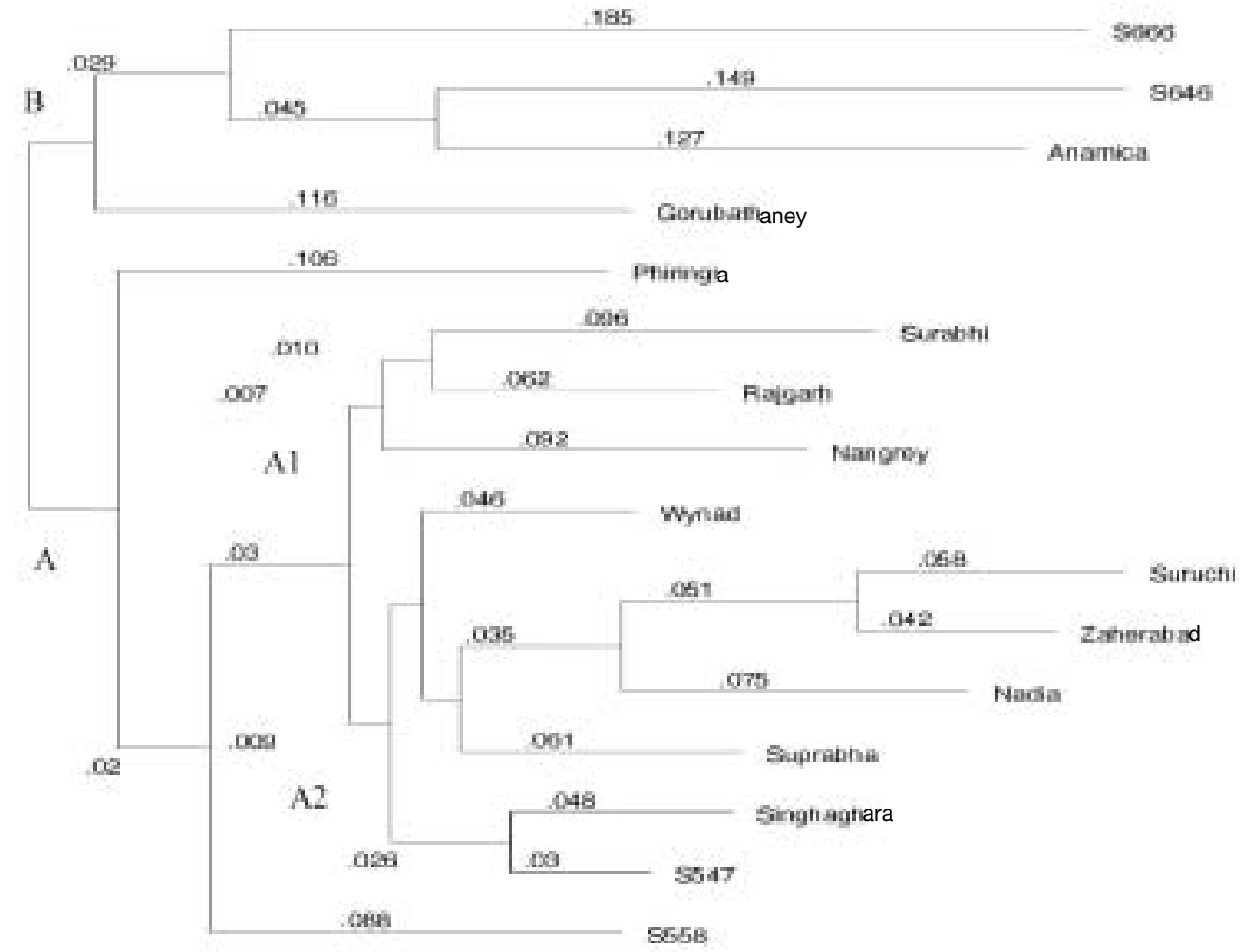

Fig. 1. Dendrogram using the neighbor-joining method of RAPD sequences showing the genomic relationship among 16 cultivars of ginger. 
Table III. Measure of distances and closeness across the cultivars of Zingiber officinale.

\begin{tabular}{rlrrrrr}
\hline $\begin{array}{c}\text { Sample } \\
\text { number }\end{array}$ & Sample name & Mean & StdDev & Number & $\begin{array}{l}\text { Closest } \\
\text { name }\end{array}$ & $\begin{array}{c}\text { Next closest } \\
\text { Distance }\end{array}$ \\
\hline 1 & Suruchi & 0.288 & 0.118 & 13 & Zaherabad & 0.101 \\
2 & Suprabha & 0.228 & 0.094 & 7 & S547 & 0.125 \\
3 & Surabhi & 0.254 & 0.068 & 16 & Rajgarh & 0.158 \\
4 & Singhaghara & 0.232 & 0.095 & 7 & S547 & 0.078 \\
5 & Phiringia & 0.271 & 0.042 & 7 & S547 & 0.200 \\
6 & S558 & 0.249 & 0.061 & 7 & S547 & 0.157 \\
7 & S547 & 0.215 & 0.094 & 4 & Singhaghara & 0.078 \\
8 & S666 & 0.388 & 0.050 & 5 & Phiringia & 0.315 \\
9 & S646 & 0.390 & 0.059 & 12 & Anamica & 0.277 \\
10 & Nangrey & 0.244 & 0.080 & 7 & S547 & 3 \\
11 & Gorubathaney & 0.303 & 0.038 & 10 & Nangrey & 5.161 \\
12 & Anamica & 0.369 & 0.047 & 9 & S646 & 0.239 \\
13 & Zaherabad & 0.274 & 0.105 & 1 & Suruchi & 0.277 \\
14 & Wynad local & 0.211 & 0.093 & 4 & Singhaghara & 0.101 \\
15 & Nadia & 0.263 & 0.102 & 14 & Wynad local & 0.111 \\
16 & Rajgarh & 0.234 & 0.094 & 14 & Wynad local & 0.148 \\
\end{tabular}

ited by the small number of cultivars available. The number of polymorphic markers varied in between 26 (in S666) to a maximum of 70 (in Suruchi) (Table I). The total number of polymorphic loci is 101, thereby giving an estimate of profound (>69.55\%) polymorphism. On an all-genotype basis, the observed number of alleles was 1.682 and the effective number of alleles was found to be 1.348 per locus. Similarly the total gene diversity $(H t)$ among cultivars was 0.213 and within cultivars $(H s)$ 0.153. Shannon's information index was 0.327 and the estimated gene flow was found to be 1.290 among 16 cultivars (Table IV). The number of significant $(p<0.05)$ linkage disequilibria $(L D)$ is 6860 across the cultivars. Whereas, gene diversity computed among different groups of cultivars was recorded in between 0.079 to 0.196 (Table V). The effective number of alleles varied from 0.320 to 1.348 across the cultivars collected from different regions. The same order of genetic heterogeneity was discerned through Shannon's information index, which varied from 0.110 to 0.283. Further, the observed polymorphism across the cultivars collected from different regions was found to be in between 15.86 to a maximum of 54.31 and presents the estimation of genetic variability among the cultivars. AMOVA analysis revealed $0.45 \%$ differences among populations.

\section{Spatial and genetic structure of genotypes}

The Mantel test results gave an $r$-value of 0.125 ( $p=0.873$, for 1000 randomizations), indicating that there is a strong isolation-by-distance effect present among the populations. However, on further investigation using spatial autocorrelation analysis, this relationship is not of a linear nature. The correlogram shows a sharp, non-linear decline in $r$ across a short geographical distance, with $r$ positive and significant at 1,2,4,13 and $14 \mathrm{~km}$ and an $x$-intercept at 3,5,12 and $15 \mathrm{~km}$. Beyond this point, the relationship remains nonsignificant.

Principle component analysis provides a field representation of the variability in a $2 \mathrm{D}$ or $3 \mathrm{D}$ set of axes. It is a very useful analysis for inspecting visually the similarity of samples since dissimilar samples will appear to be further apart than highly similar samples. No specific clustering of the 16

Table IV. Genetic variability across all the cultivars of Zingiber officinale.

\begin{tabular}{lllllllll}
\hline $\begin{array}{l}\text { Observed } \\
\text { no. of } \\
\text { alleles }\end{array}$ & $\begin{array}{l}\text { Effective } \\
\text { no. of } \\
\text { alleles }\end{array}$ & $\begin{array}{l}\text { Nei's } \\
\text { gene } \\
\text { diversity }\end{array}$ & $\begin{array}{l}\text { Shannon's } \\
\text { information } \\
\text { index }\end{array}$ & $H t$ & $H s$ & $\begin{array}{l}\text { Estimate } \\
\text { of gene } \\
\text { flow }\end{array}$ & G $^{2}$ & $\begin{array}{l}\text { No. of } \\
\text { polymorphic } \\
\text { alleles }\end{array}$ \\
\hline $\begin{array}{l}1.682 \\
(0.467)\end{array}$ & $\begin{array}{l}1.348 \\
(0.340)\end{array}$ & $\begin{array}{l}0.213 \\
(0.183)\end{array}$ & $\begin{array}{l}0.327 \\
(0.261)\end{array}$ & $\begin{array}{l}0.213 \\
(0.033)\end{array}$ & $\begin{array}{l}0.153 \\
(0.018)\end{array}$ & 1.290 & $\begin{array}{l}12.057 \\
(p=0.675)\end{array}$ & 99 \\
\hline
\end{tabular}


Table V. Genetic variability across the cultivars of Zingiber officinale with respect to the region from where they are collected.

\begin{tabular}{|c|c|c|c|c|c|c|c|c|}
\hline $\begin{array}{l}\text { Cultivars } \\
\text { sampling } \\
\text { site }\end{array}$ & $\begin{array}{l}\text { Sample } \\
\text { size }\end{array}$ & $\begin{array}{l}\text { Observed } \\
\text { no. of } \\
\text { alleles }\end{array}$ & $\begin{array}{l}\text { Effective } \\
\text { no. of } \\
\text { alleles }\end{array}$ & $\begin{array}{l}\text { Nei's gene } \\
\text { diversity }\end{array}$ & $\begin{array}{l}\text { Shannon's } \\
\text { information } \\
\text { index }\end{array}$ & $H t$ & $\begin{array}{l}\text { Sum of } \\
\text { polymorphic } \\
\text { loci using all } \\
\text { primers }\end{array}$ & $\begin{array}{l}\text { Polymorphic } \\
\text { loci }(\%)\end{array}$ \\
\hline Orissa & 5 & $\begin{array}{l}1.421 \\
(0.492)\end{array}$ & $\begin{array}{l}1.267 \\
(0.344)\end{array}$ & & $\begin{array}{l}0.237 \\
(0.284)\end{array}$ & $\begin{array}{l}0.159 \\
(0.037)\end{array}$ & 73 & 54.31 \\
\hline Solan & 4 & $\begin{array}{l}1.462 \\
(0.500)\end{array}$ & $\begin{array}{l}1.348 \\
(0.401)\end{array}$ & $\begin{array}{l}0.196 \\
(0.216)\end{array}$ & $\begin{array}{l}0.283 \\
(0.310)\end{array}$ & $\begin{array}{l}0.196 \\
(0.047)\end{array}$ & 67 & 46.21 \\
\hline Sikim & 2 & $\begin{array}{l}1.159 \\
(0.367)\end{array}$ & $\begin{array}{l}1.159 \\
(0.367)\end{array}$ & $\begin{array}{l}0.079 \\
(0.183)\end{array}$ & $\begin{array}{l}0.110 \\
(0.254)\end{array}$ & $\begin{array}{l}0.079 \\
(0.034)\end{array}$ & 23 & 15.86 \\
\hline Andhra & 3 & $\begin{array}{l}1.400 \\
(0.492)\end{array}$ & $\begin{array}{l}0.320 \\
(0.393)\end{array}$ & $\begin{array}{l}0.178 \\
(0.218)\end{array}$ & $\begin{array}{l}0.255 \\
(0.313)\end{array}$ & $\begin{array}{l}0.178 \\
(0.048)\end{array}$ & 58 & 40.00 \\
\hline $\begin{array}{l}\text { West } \\
\text { Bengal }\end{array}$ & 2 & $\begin{array}{l}1.186 \\
(0.391)\end{array}$ & $\begin{array}{l}1.186 \\
(0.391)\end{array}$ & $\begin{array}{l}0.093 \\
(0.195)\end{array}$ & $\begin{array}{l}0.129 \\
(0.271)\end{array}$ & $\begin{array}{l}0.093 \\
(0.038)\end{array}$ & 27 & 18.62 \\
\hline
\end{tabular}

cultivars was observed indicating a wide genetic variation among themselves.

In this study we have identified 101 polymorphic bands and only 44 monomorphic bands across all genotypes tested. Polymorphism detection efficiency among promising ginger cultivars by RAPDs compared favorably with other available marker systems. The number of polymorphic loci per assay is important for cultivar identification. Finding of wide genetic distances reveals relatively high genetic variation among the 16 cultivars. The considerable polymorphism detected in this study also illustrated that it is possible to find genetic divergence among ginger cultivars of the same origin. This result is supported by Sera et al. (2003) among coffee cultivars. Further the high levels of allelic diversity of RAPD markers observed in this study probably were associated with the extensive range of genetic diversity represented in the panel of ginger genotypes. This result was similar to that of Agrama and Tuinstra (2003) among sorghum cultivars. These studies indicate that RAPD mark- ers provide a more reliable method than morphological characters to identify closely related turmeric cultivars. The large difference in gene diversity among cultivars reveals the presence of strong genetic structure between them and thus significant differences exist in the genotypic diversity among themselves. Some variability could, however, be due to the different environmental conditions experienced by the cultivar. Further studies addressing this point directly are required before any robust hypothesis can be formulated, however.

\section{Acknowledgements}

The authors are grateful to Dr. Y. Medury, ViceChancellor and Brig. Balbir Singh, Registrar of Jaypee University of Information Technology for providing facilities and encouragement throughout. Financial assistance from DST, New Delhi is gratefully acknowledged. 
Aagaard J. E., Krutovskii K. V., and Strauss S. H. (1998), RAPDs and allozymes exhibit similar levels of diversity and differentiation among populations and races of Douglas-fir. J. Heredity 11, 69-78.

Agrama H. A. and Tuinstra M. R. (2003), Phylogenetic diversity and relationships among Sorghum accessions using SSRs and RAPDs. African J. Biotech 2, 334-340.

Bennett M. D. and Smith J. B. (1991), Nuclear DNA amounts in angiosperms. Philos. Trans. R. Soc. London B334, 309-345.

Das A. B., Rai S., and Das P. (1998), Karyotype analysis and 4C DNA content in some cultivars of ginger (Zingiber officinale Rosc.). Cytobios 93, 175-184.

Das A. B., Mukherjee A. K., and Das P. (2001), Molecular phylogeny of Heritiera aiton (Sterculiaceae), a tree mangrove: variation in RAPD markers and nuclear DNA content. Botanical J. Linn. Soc. 136, 221-229.

Doyle J. J. and Doyle J. J. (1990), Isolation of plant DNA from fresh tissue. Focus 12, 13-15.

Excoffier L., Smouse P. E., and Quattro J. M. (1992), Analyses of molecular variance inferred from metric distances among DNA haplotypes: application to human mitochondrial DNA restriction data. Genetics 131, 479-491.

Flavell R. B., Rimpau J., and Smith D. B. (1977), Repeated sequence DNA relationships in four cereal genomes. Chromosoma 63, 5-22.

Frankel O. H., Brown A. H. D., and Burdon (1995), The Conservation of Plant Biodiversity. Cambridge University Press, Cambridge, UK.

Friesen N. and Blattner F. R. (2000), RAPD analysis reveals geographic differentiations within Allium schoenoprasum L. (Alliaceae). Plant Biol. 2, 297-305.

Ho C. Y., McMaugh S. J., Wilton A. N., McFarlane I. J., and Mackinlay A. G. (1997), DNA amplification variation within cultivars of turf type couch grasses (Cyanodon spp.). Plant Cell Rep. 16, 797-801.

Huang H., Layne D. R., and Kulisiak T. L. (2000), RAPD inheritance and diversity in pawpaw (Asimina triloba). J. Am. Soc. Hortic. Sci. 125, 454-459.

Martel E., Denay D., Siljakyakovlev S., Brown S., and Sarr A. (1997), Genome size variation and basic chromosome number in pearl millet and fourteen related Pennisetum species. J. Heredity 88, 139-143.
Mohanty D. C. and Panda B. S. (1994), Genetic Resources of Ginger. Advances in Horticulture (Chadha K. L. and Rethinam P., eds.). Malhotra Publishing House, New Delhi, India, pp. 151-168.

Morell M. K., Peakall R., Appels R., Preston L. R., and Lloyd H. L. (1995), DNA profiling technique for plant variety identification. Aust. J. Exp. Agri. 35, $807-819$.

Nei M. (1973), Analyses of gene diversity in subdivided populations. Proc. Natl. Acad. Sci. USA 70, 33213323.

Prevost A. and Wilkinson M. J. (1999), A new system of comparing PCR primers applied to ISSR fingerprinting of potato cultivars. Theor. Appl. Genet. 98, 107112.

Price H. J., Bachman K., Cihambers K. L., and Riggs J. (1980), Detection of interspecific variation in nuclear DNA content in Microseris douglasii. Bot. Gaz. 141, 195-198.

Rodriguez J. M., Berke T., Engle L., and Nienhuis J. (1999), Variation among and within Capsicum species revealed by RAPD markers. Theor. Appl. Genet. 99, $147-156$.

Schneider S., Roessli D., and Excoffier L. (2001), Arlequin: A Software for Population Genetics Data Analyses, Version 2001. Genetics and Biometry Lab, Department of Anthropology, University of Geneva, Geneva.

Schnell R. J., Ronning C. M., and Knight R. J. (1995), Identification of cultivars and validation of genetic relationship in Mangifera indica L. using RAPD markers. Theor. Appl. Genet. 90, 269-274.

Sera T., Ruas P. M., Ruas C. F., Diniz L. E. C., Carvalho V. P., Rampin L., Ruas E. A., and Silveira S. R. (2003), Genetic polymorphism among 14 elite Coffea arabica L. cultivars using RAPD markers associated with restriction digestion. Genet. Mol. Biol. 26, 59-64.

Sharma A. K. and Sharma A. (1980), Chromosome Techniques: Theory and Practice, $3^{\text {rd }}$ ed. Butterworths, London.

Williams J. G. K., Kubelik A. R., Livak K. J., Rafalski J. A., and Tingey S. V. (1990), DNA polymorphisms amplified by arbitrary primers are useful as genetic markers. Nucl. Acids Res. 18, 6531-6535. 